\section{Tuberculosis dynamics from spatial analysis: integrative review}

\section{Dinâmica da tuberculose a partir de análise espacial: revisão integrativa}

\section{Dinámica de la tuberculosis a partir del análisis espacial: revisión integradora}

Shirley Verônica Melo Almeida Lima ${ }^{1,2}$, Monique Dinízio dos Santos ${ }^{1}$, Liana Dantas Silva ${ }^{1}$, Jéssica Carvalho Nascimento ${ }^{1}$, Allan Dantas dos Santos ${ }^{1}$, Elias Teixeira de Oliveira ${ }^{3}$, Karina Conceição Gomes Machado de Araújo $^{2}$, Marco Antonio Prado Nunes ${ }^{2}$

\footnotetext{
${ }^{1}$ Federal University of Sergipe, Nursing Department, Lagarto, Sergipe, Brazil.

${ }^{2}$ Federal University of Sergipe, Graduate Program in Health Sciences, São Cristóvão, Sergipe, Brazil.

${ }^{3}$ University of São Paulo, Nursing Department, Ribeirão Preto, São Paulo, Brazil.
}

\begin{abstract}
Objective: to analyze from literature, the contributions of spatial analysis to comprehend the tuberculosis dynamics. Method: integrative review of literature preformed within 2008 to 2017, developed from published manuscripts in any language on LILACS, PubMed and SCOPUS databases. Results: 140 studies were retrieved, of which 50 were included. The main findings refer to predominance of the use of tuberculosis incidence rates as outcome variable and its association with social and geographic conditions. The American continent presented the highest number of studies, although the African countries presented the highest incidence rates. Conclusion: the complexity of tuberculosis incidence in the geographic space is associated with epidemiologic factors. The spatial analysis presents advancements for the management of tuberculosis worldwide allowing identifying inequalities and health conditions of a population.
\end{abstract}

Descriptors: Tuberculosis; Spatial Analysis; Epidemiology; Review.

\section{RESUMO}

Objetivo: analisar a partir da literatura, as contribuições da análise espacial para compreender a dinâmica da tuberculose. Método: revisão integrativa da literatura realizada no período de 2008 a 2017, desenvolvida a partir de manuscritos publicados em qualquer idioma nas bases de dados LILACS, PubMed e SCOPUS. Resultados: foram resgatados 140 estudos, dos quais 50 incluídos. Os principais achados referem-se à predominância do uso das taxas de incidência de tuberculose como variável de desfecho e sua associação com as condições sociais e geográficas. 0 continente americano apresentou o maior número de estudos, apesar dos países africanos apresentarem as maiores taxas de incidência. Conclusão: a complexidade da incidência da tuberculose no espaço geográfico está associada aos fatores epidemiológicos. A análise espacial representa avanços para o gerenciamento da tuberculose mundialmente permitindo identificar desigualdades e condições de saúde de uma população.

Descritores: Tuberculose; Análise Espacial; Epidemiologia; Revisão.

\section{RESUMÉN}

Objetivo: Analizar a partir de la literatura las contribuciones del análisis espacial para comprender la dinámica de la tuberculosis. Método: revisión bibliográfica integradora realizada entre 2008 y 2017, desarrollada a partir de manuscritos publicados en cualquier idioma en las bases de datos LILACS, PubMed y SCOPUS. Resultados: se rescataron 140 estudios, de los cuales se incluyeron 50. Los principales hallazgos se refieren al predominio del uso de tasas de incidencia de tuberculosis como variable de resultado y su asociación con condiciones sociales y geográficas. El continente americano presentó el mayor número de estudios, aunque los países africanos tuvieron las tasas de incidencia más altas. Conclusión: La complejidad de la incidencia de tuberculosis en el espacio geográfico está asociada a factores epidemiológicos. El análisis espacial representa los avances en el manejo de la tuberculosis en todo el mundo, lo que permite identificar las desigualdades y las condiciones de salud de una población.

Descriptores: Tuberculosis; Análisis Espacial; Epidemiología; Revisión.

\section{How to cite:}

Lima SVMA, dos Santos MD, Silva LD, Nascimento JC, dos Santos AD, de Oliveira ET, et al. Tuberculosis dynamics from spatial analysis: integrative review. Rev Pre Infec e Saúde [Internet]. 2019;5:9194. Available from: http://www.ojs.ufpi.br/index.php/nupcis/article/view/9194 DOI: https://doi.org/10.26694/repis.v5i0.8822

Rev Pre Infec e Saúde. 2019;5:9194 


\section{INTRODUCTION}

Tuberculosis (TB) is a disease caused by a slow growth bacillus, Mycobacterium tuberculosis, strict aerobic, acid-alcohol resistant (BAAR), of aerogenous transmissibility, that mainly affects lungs. It is closely related to poverty, poor living and housing conditions and human agglomeration. ${ }^{1}$

Although government implementation of various control and vigilance strategies, TB persists as a big public health problem. ${ }^{2}$ It is estimated that one third of world population is infected by Koch bacillus. The African and Asian regions are the ones that present most risk of illness. Six countries were responsible for $60 \%$ of new worldwide TB cases in 2015: India, Indonesia, China, Nigeria, Pakistan and South Africa. The global progress to fight the disease depends on advancements in patient prevention and care in all the countries with high TB load, among them Brazil. ${ }^{3}$

The TB issue reflects the social development stage of the country, in which poverty determinants, poor sanitary conditions, significative increase of acquired immune deficiency syndrome (AIDS) cases, populational growth, large migratory movements and lack of management organization and health services limit the measures for eradication of the disease, keeping it endemic mainly in the most vulnerable populations, justifying the persistence of $T B$ as serious public health problem. ${ }^{4-5}$

Developing countries, such as Brazil, are those that present the highest incidence rates of the disease because they share some common characteristics in high-risk global regions, as the high urbanization index, high social inequality and ethnic and cultural diversity as well as the neglected control by public policies and society, making it difficult to comprehend the disease dynamics and responsiveness. ${ }^{6}$

In the last decades, the development of new statistical techniques deployed to epidemiology as well as the use of computers and creation of new programs have helped in a better comprehension of the health-disease process, making the application of analyses from data obtained in epidemiologic investigations accessible to an increasing number of researchers by extracting elements that contribute to minimize the health problems of society. Also, elements for the orientation of intersectoral actions that contribute to decision making have been provided. ${ }^{7}$

In this sense, the use of technologies that can subsidize the decision making, organizing and planning actions to eradicate TB is substantial. The geographic information systems associated with geoprocessing techniques constitute a big tool for TB monitoring, control and evaluation, as they lead to distribution dynamics understanding between illness and death risks because it allows an evaluation of TB distribution and its populational determinants in space and time. ${ }^{2,8}$

Therefore, it was chosen as objective to analyze from the literature the contributions of spatial analysis for comprehending TB dynamics.

\section{METHOD}

\section{Study outline}

Integrative review of literature aiming to answer the following question: what are the main contributions of spatial analysis for 
Lima SVMA, et al.

comprehending the tuberculosis (TB) dynamics over the years?

\section{Exclusion and inclusion criteria}

All the original manuscripts with complete availability on LILACS, PubMed and SCOPUS databases, indexed within January 1, 2008 to December 31, 2017, written in any language, that cover the use of spatial analysis for the study of TB in human beings were included.

Media news and manuscripts: about animals, review, incomplete, paid, thesis, dissertations were excluded.

\section{Definition of databases, descriptors and search strategies}

As search source, finished and published national and international manuscripts with free public access that described the techniques of spatial analysis associated to TB control and prevention, within 2008 to 2017 in world population were utilized. The search strategies were employed according to the norms of each selected electronic database.

Aiming to perform a broad search and reduce the possibility of bias, the utilized terms were defined by means of search in controlled vocabularies: Medical Subject Headings (MeSH) and Descritores em Ciências da Saúde (DeCS). These vocabularies gather a range of descriptors and synonyms organized in importance order, ensuring the search execution in scientific and technical literature related to health.

The search included as descriptors: Tuberculose; Tuberculose AND Análise Espacial, Tuberculose AND Sistema de Informação Geográfica; Tuberculose AND Geoprocessamento
Tuberculosis dynamics from spatial analysis em Saúde. As well as their synonyms: TB; Pneumologia Sanitária; Geomática; Estimativa de Densidade Kernel.

\section{Collect and data analysis instrument}

To reach the objective, a bibliographic instrument was made, and it allowed each article to be analyzed separately, according to the preestablished purposes. This instrument provided advantages such as: the systematization in collecting information, later article retrieval, selection of articles of excellence, identification of methodological problems and comparison with other works.

The instrument contemplates the items: identification, publication type, methodological characteristics of study, data treatment and statistical analysis, techniques of spatial analysis, results, description of sample aggregation level, main findings and implications in addition to identify limitations or bias.

After the selection of manuscripts, the data were tabulated in Microsoft Excel ${ }^{\circledR}$ program.

\section{RESULTS}

A primary selection of 140 published manuscripts was performed. After the initial evaluations, 27 articles were excluded just by reading the title and for being duplicates. After this exclusion, 113 references remained, of which 43 were excluded by reading the abstract, and 2 were excluded due to its absence. Among the 68 remained ones, 18 were excluded after reading the whole text, remaining 50 articles for systematic review (Figure 1). 
Figure 1: Flux of selection of studies retrieved in integrative review about tuberculosis and Spatial Analysis over the world, 2008 to 2017.

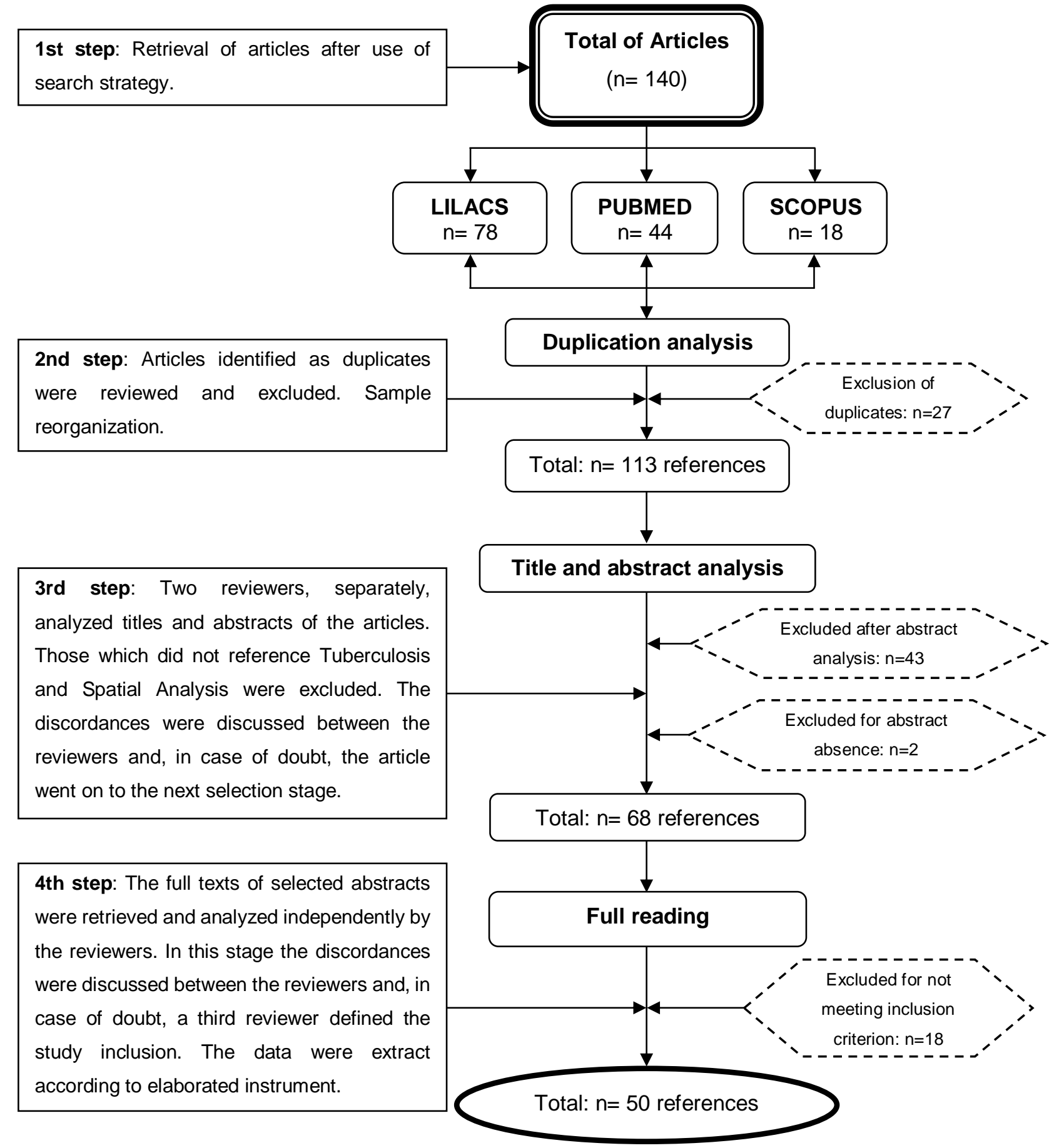

General characteristics of the studies were showed on Table 1 and in categories of social determinants, strategic measures to fight tuberculosis (TB) and spatial factors for TB control, which point out aspects of objectives, theme discussion, independent variables, outcome variable and conclusion of studies.

Rev Pre Infec e Saúde. 2019;5:9194
The findings identify that 38 articles (76\%) correspond to recent publications starting from 2013. As for the place where the study was performed, twenty eight were developed in America: four in North America and twenty four in South America; fourteen were in Asia: eleven in East Asia and three in West Asia; and eight 
Lima SVMA, et al.

studies in Africa: three in Central Africa and three in South Africa. It was evidenced that the aggregation level of sample composed 20 articles (40\%) performed in Cities; 6 articles (12\%) in Countries; Census Tracts, Neighborhoods and Provinces 5 articles each (10\%); 4 articles (8\%) in Districts; 3 articles (6\%) in States; Counties and Regions 1 article each (2\%) (Table 1).
Tuberculosis dynamics from spatial analysis

Regarding the study type, 40 articles (80\%) were type Ecological, and the other articles type: retrospective, transversal, temporal, descriptive, temporal tendency and ecological, historic/cohort/ecological, epidemiological, control case/ecological, and descriptive spatial. (Table 1).

Table 1: Study place, study type and aggregation level of manuscripts selected in the systematic review, 2008 to 2017.

\begin{tabular}{|c|c|c|c|}
\hline \multicolumn{2}{|c|}{ Study characteristics } & \multirow{2}{*}{$\begin{array}{c}(n=50) \\
4\end{array}$} & \multirow{2}{*}{$\begin{array}{l}\% \\
8\end{array}$} \\
\hline \multirow{7}{*}{ Study Place } & North America & & \\
\hline & South America & 24 & 48 \\
\hline & East Africa & 3 & 6 \\
\hline & Central Africa & 2 & 4 \\
\hline & South Africa & 3 & 6 \\
\hline & East Asia & 11 & 22 \\
\hline & West Asia & 3 & 6 \\
\hline \multirow{10}{*}{ Study Type } & Ecologic & 40 & 80 \\
\hline & Retrospective & 2 & 4 \\
\hline & Transversal & 1 & 2 \\
\hline & Temporal & 1 & 2 \\
\hline & Descriptive and Spatial & 1 & 2 \\
\hline & Temporal tendency and Ecologic & 1 & 2 \\
\hline & Historic / Cohort / Ecologic & 1 & 2 \\
\hline & Epidemiologic & 1 & 2 \\
\hline & Control case / Ecologic & 1 & 2 \\
\hline & Descriptive & 1 & 2 \\
\hline \multirow{9}{*}{ Aggregation Level } & City & 20 & 40 \\
\hline & Country & 6 & 12 \\
\hline & Census tract & 5 & 10 \\
\hline & Province & 5 & 10 \\
\hline & Neighborhood & 5 & 10 \\
\hline & District & 4 & 8 \\
\hline & State & 3 & 6 \\
\hline & County & 1 & 2 \\
\hline & Region & 1 & 2 \\
\hline
\end{tabular}

In the analysis of outcome variables, the predominance of TB incidence and prevalence cases were observed, and coinfection and mortality cases were cited.

Among the analyzed independent variables, the following predominated: sociodemographic (age range, sex, race/color, marital status, occupation, educational level, address, sanitation); socioeconomic (income, Human Development Index); clinic; epidemiologic; etiopathogenic and climatic/geographic/environmental. Among the 
variables related to treatment, it is worth noting: diagnosis date, clinical evolution, use of prophylaxis, treatment type and finish date, directly observed treatment and treatment adherence.

Among the analyzed studies, distinct models of spatial analysis were found, in which more than one type of analysis were present in the most part of analyzed studies. The predominant models were: kernel density estimation; spatial distribution; Poisson model; Kulldorff model; Bayesian model; K-function; statistical scan; Moran analysis; spatial regression; Monte Carlo simulation; kriging method; and permute scan.

Didactically, the main results were grouped in the following categories, considering theme, objectives and main results of each one of the analyzed manuscripts:

\section{Social Determinants}

Spatial analysis evidence direct relations between social determinants and TB. ${ }^{9}$ Relations evidenced by the inverse association between the socioeconomic status and TB incidence, relation between vulnerability, socioeconomic and sociodemographic condition, mortality and coinfection by HIV-TB. ${ }^{10-21}$ The vulnerability was also observed among indigenous people, in the data of child mortality due to HIV-TB coinfection, being 3 times higher in orphan children, along with in the difficult adherence to the TB treatment and poor living conditions of people subjected to such circumstances. ${ }^{22-24}$

\section{Strategic measures to fight tuberculosis}

The studies showed that the spatial analysis is an extremely important tool in statistically significant data collection and indicators to subsidize strategic actions for TB prevention and control. ${ }^{25-26}$ Thus, it was possible to identify endemic and coendemic areas (HIV-TB; Intestinal Infection by Helminths-TB), regions with late diagnoses, cases of avoidable hospital stay, the incidence control of infantile TB, with focus in primary care. ${ }^{27-32}$

The analysis of spatial distribution enables, also, the identification of regions with death toll and TB cases, thus contributing to the action planning of territorial base, granting subsidies to figure out strategies to reduce inequities in health and limits for the increasing TB incidence. ${ }^{33-34}$

Qualified investment in TB control, reformulation and restructuration of policies and health services are essential to control the cases (TB and TB-HIV) and generate positive effects on reducing the incidence in population. ${ }^{35-36}$ Strategic measures of prevention are urgent to the incidence control and decreasing in significantly affected regions, reinforce the need for technologies such as geocodification and genotyping as important tools in TB control and prevention in priority areas, the utilization of spatial analysis to identify local particularities, geographic, cultural and socioeconomic differences, valuing the specific needs of educative actions about the disease. ${ }^{37-44}$

\section{Special factors for the tuberculosis control}

It was possible to identify that the TB spatial distribution occurs in a heterogeneous and nonrandom way in the analyzed regions, also evidencing that the TB incidence was positively 
associated to temperature, precipitation and wind speed, while socioeconomic and geographic factors were considered as covariables. These factors had impact in regional differences of TB prevalence..$^{45-49}$

\section{DISCUSSION}

The use of techniques of statistical analysis by the authors of selected studies can be justified due to its relevance to estimate correlations between tuberculosis (TB) occurrence and spatial dependence. It is important to have a geospatial perspective in TB epidemiology to clearly comprehend the factors that influence spatial variations and dissemination of pathogenesis of worldwide TB. ${ }^{50}$

The understanding of TB depends on the spatial disposition of infectious agent, host and the possibility of the encounter of both, with spatial analysis and geographic information system (GIS) being important tools for its control, as they identify factors that contribute to its dissemination and make evident areas with high incidence rates. ${ }^{8}$

The outcome analysis as TB incidence points out the persistence of relation between socioeconomic and demographic factors in disease reproduction, once the low social and economic level may worsen the life conditions of the individual, making him vulnerable. This assertive corroborates with the findings of San et al. ${ }^{51}$ study, that by investigating through a systematic review the existence of association between socioeconomic factors and the TB occurrence, describe that the incident and prevalent cases indicate a positive association with sex, age, illiteracy, low income, marital status, food deprivation, previous contact with TB patient and coinfection with HIV, with this variables being also found in the present study.

It is worth noting that lack of social opportunities excludes part of the population from conditions of dignity and citizenship, placing them at a disadvantage in relation to availability and access to technologies and health services, which may contribute for a late diagnosis of the disease and/or treatment abandonment.

Moreover, the public policies not always have produced actions aimed to fulfill the needs and social reality of priority territories, reaffirming in this context the importance of the spatial analysis and GIS. ${ }^{52}$ Santos-Neto and their collaborators reiterate that areas devoid of decent housing and sanitation also tend to approve services with little resolvability and large limitations. ${ }^{34}$

A discrepancy of those results compared with the Ximenes et al and Barcellos was observed because the latter affirm that the socioeconomic and epidemiologic indicators do not act in an isolated way, inferring the existence of particular characteristics inherent to the aggregation level of sample that should be considered in analyses since the environment is result of historical, environmental and social situations, proving the influence of particular characteristics of geographical areas..$^{53-54}$

In the context of public health, various studies have used the technologies in health for risk analysis and information of a given disease, but they are still little used to this purpose..$^{50,55}$ Most of the studies considered for this review choose city as spatial unity of analysis, but a careful analysis of each neighborhood is more 
recommended, forming micro-areas, facilitating the qualification of areas based on collective and individual risk indicators. ${ }^{56}$

Similar findings are also found by Brazilian authors, which defend that for the definition of priorities the cities should be stratify in distinct areas, according to life conditions, generating a better detailing of the place of disease occurrence, by means of home addresses, coordinates surveyed in field with the help of GPS or even detailing of census tracts for making indicators, considering the territoriality in health that enables a real spatial view of the aggravation..$^{55,57}$

It was found that $48 \%$ of studies were performed in South America. Discrepancy was detected when the TB magnitude concentrated in the Asian and African region was analyzed: the most critical areas merge with the geographic representation of extreme poverty and underdeveloped countries, realizing that African countries present the highest incidence rates, followed in descending order by Southeast Asia, Latin America, Europe and North America regions. ${ }^{58}$ In this way, it is suggested to intensify studies aimed at the most critical geographical areas.

This study presented limitations because it is an integrative review, and the results reflect only an instant picture of reality and do not allow comparing interventions, because they are most of time populational studies, not experimental ones. ${ }^{59}$ The aggregate information about the epidemiologic situation and TB spatial distribution in world stage show that they themselves can be used to direct measures to correct flaws that still exist in health systems and in the disease prevention and control.

\section{CONCLUSION}

We highlight that the spatial analysis in health represents a great advancement for the management of tuberculosis worldwide, by means of mapping the risk places, that allows identifying inequalities and detailing the health conditions of a population. The aggregating information about the epidemiologic situation and spatial distribution of tuberculosis in world stage show that they themselves can be used to direct measures to correct flaws that still exist in health systems and in the disease prevention and control.

The monitoring strategies are based on geospatial studies that reveal the reality of each region, presenting as a viable alternative for different public sectors. The articulation with local programs for a better direction of interventions is necessary, but only public policies are not enough, it should have political interest in investments and strategies that aim to reduce the inequities and social responsibility of disease, factor that would allow the optimization of material, financial and human resources.

\section{REFERENCES}

1. Duarte IGT, Silva ID, Nogueira FFA, Costa MS, Moreira MRC. Perfil epidemiológico da tuberculose na cidade de Uiraúna-Paraíba
[Apresentação no IV Encontro Universitário da UFC no Cariri; 2013 dez 17-19; Juazeiro do Norte, Brasil].

Available

from: 
https://encontros.ufca.edu.br/index.php/encon tros-universitarios/eu-

2012/paper/viewFile/1345/793

2. Daronco A, Borges TS, Sonda EC, Lutz B, Rauber $A$, Battisti $F$ et al. Spatial distribution of cases of tuberculosis in Santa Cruz do Sul a priority municipality of Rio Grande do Sul State, Brazil 2000 to 2010. Epidemiol Serv Saúde [Internet]. 2012 Nov [cited 2019 Jun 15]; 21(4): 645-654. Available from: http://dx.doi.org/10.5123/S1679-

\section{4}

3. Brasil. Ministério da Saúde. Secretaria de Vigilância em Saúde. Departamento de Vigilância das Doenças Transmissíveis. Brasil livre da tuberculose: plano nacional pelo fim da tuberculose como problema de saúde pública. 1. ed. Brasília: MS, 2017. Available from: http://bvsms.saude.gov.br/bvs/publicacoes/bra sil_livre_tuberculose_plano_nacional.pdf

4. Queiroga RPF, Sá LD, Nogueira JA, Lima ERV, Silva ACO, Pinheiro PGOD et al. Spatial distribution of tuberculosis and relationship with living conditions in an urban area of Campina Grande - 2004 to 2007. Rev bras epidemiol [Internet]. 2012 Mar [cited 2019 Jun 15]; 15(1):222-232. Available from: http://dx.doi.org/10.1590/S1415-

790X2012000100020

5. Barbosa IR, Pereira LMS, Medeiros PFM, Valentim RS, Brito JM, Costa ICC. Spatial distribution analysis of tuberculosis in Northeastern Brazil, 2005-2010. Epidemiol Serv Saúde [Internet]. 2013 Dez [cited 2019 Jun 15]; 22(4): 687-695. Available from: http: / /dx.doi.org/10.5123/S1679-

\section{5}

6. Pinto ML. Spatial patterns of TB cases reported in the city of Cajazeiras / PB - 2001-2010. 2013. 25p. Work of Academic Conclusion - TCC (Bacharel and Graduation Nursing). Campina Grande: Universidade estadual da Paraíba, Campina Grande, 2013. Available from: http://dspace.bc.uepb.edu.br/jspui/bitstream/ 123456789/4325/1/PDF\%20-

\%20Maryana\%20Lima\%20Pinto.pdf

7. Barreto ML. The role of epidemiology in the development of the National Health System in Brazil: background, foundation and prospects. Rev Pre Infec e Saúde. 2019;5:9194
Rev bras epidemiol [Internet]. 2017 Nov [cited 2019 Jun 15]; 5(Suppl 1):4-17. Available from: http://dx.doi.org/10.1590/S1415790X2002000400003

8. Sperli GMSN, Sperli GSML, Figueiredo VSH, Villa TCS, Ruffino-Netto A, Chiaravalloti NF et al. Tuberculosis and Spatial Analysis: Literature Review. Cienc enferm [Internet]. 2014 Ago [cited 2019 Jun 15]; 20(2):117-129. Available from: http://dx.doi.org/10.4067/S0717-

95532014000200012

9. Sun W, Gong J, Zhou J, Zhao Y, Tan J, Ibrahim A, et al. A spatial, social and environmental study of tuberculosis in China using statistical and GIS technology. Int J Environ Res Public Health [Internet]. 2015 Nov [cited 2019 Jun 15]; 12(2):1425-1448. Available from: https://doi.org/10.3390/ijerph120201425

10. Oren E, Koepsell T, Leroux, BG, Mayer J. Areabased socio-economic disadvantage and tuberculosis incidence. Int J Tuberc Lung Dis [Internet]. 2012 Nov [cited 2019 Jun 15]; 16(7): 880-885. Available from: https://doi.org/10.5588/ijtld.11.0700

11. Brunello MEF, Chiaravalloti NF, Arcêncio RA, Andrade RLP, Magnabosco GT, Villa TCS. Areas of vulnerability to HIV/TB co-infection in Southeastern Brazil. Rev Saúde Pública [Internet]. 2011 Jun [cited 2019 Jun 15]; 45(3):556-563. Available from: http://dx.doi.org/10.1590/S003489102011005000018

12. Lima MS, Martins-Melo FR, Heukelbach J, Alencar CH, Boigny RN, Ramos JAN. Mortality related to tuberculosis-HIV/AIDS co-infection in Brazil, 2000-2011: epidemiological patterns and time trends. Cad Saúde Pública [Internet]. 2016 Oct [cited 2019 Jun 15]; 32(10):1-10. Available from: $\quad$ http://dx.doi.org/10.1590/0102$311 \times 00026715$

13. Yakam AN, Noeske J, Dambach P, Bowong S, Fono LA, Ngatchou-Wandji J. Spatial analysis of tuberculosis in Douala, Cameroon: clustering and links with socio-economic status. Int J Tuberc Lung Dis [Internet]. 2014 Nov [cited 2019 Jun 15]; 18(3):292-297. Available from: https://doi.org/10.5588/ijtld.13.0573

14. Vendramini SHF, Santos NSGM, Santos MLSG, Chiaravalloti-Neto F, Ponce MAZ, Gazetta CE, et 
al. Spatial analysis of tuberculosis/HIV coinfection: its relation with socioeconomic levels in a city in south-eastern Brazil. Rev Soc Bras Med Trop [Internet]. 2010 Oct [cited 2019 Jun 15]; 43(5):536-541. Available from: http://doi.org/10.1590/S0037-

\section{3}

15. Silva MDA, Oliveira CDL, Neto RGT, Camargos PA. Spatial distribution of tuberculosis from 2002 to 2012 in a midsize city in Brazil. BMC Public Health [Internet]. 2016 Nov [cited 2019 Jun 15]; 16(1):1-12. Available from: http://doi.org/10.1186/s12889-016-3575-y

16. Berra TZ, Queiroz AAR, Yamamura M, Arroyo LH, Garcia MCC, Popolin MP, et al. Spatial risk of tuberculosis mortality and social vulnerability in Northeast Brazil. Rev Soc Bras Med Trop [Internet]. 2017 Set [cited 2019 Jun 15]; 50(5):693-697. Available from: http: //dx.doi.org/10.1590/0037-8682-0160-2017 17. Roza DL, Caccia-Bava MCGG, Martinez EZ. Spatio-temporal patterns of tuberculosis incidence in Ribeirão Preto, State of São Paulo, southeast Brazil, and their relationship with social vulnerability: a Bayesian analysis. Rev Soc Bras Med Trop [Internet]. 2012 Oct [cited 2019 Jun 15]; 45(5):607-615. Available from: http://dx.doi.org/10.1590/S0037-

\section{3}

18. Pedro AS, Gibson G, Santos JPC, Toledo LM, Sabroza PC, Oliveira RM. Tuberculosis as a marker of inequities in the context of socio-spatial transformation. Rev. Saúde Pública [Internet]. 2017 Nov [cited 2019 Jun 15]; 51:1-9. Available from: http://dx.doi.org/10.1590/s15188787.2017051006533

19. Acosta LMW, Bassanesi SL. The Porto Alegre paradox: social determinants and tuberculosis incidence. Rev bras epidemiol [Internet]. 2014 Nov [cited 2019 Jun 15]; 17(Suppl 2):88-101. Available from: http://dx.doi.org/10.1590/18094503201400060008

20. Erazo C, Pereira SM, Costa MDCN, EvangelistaFilho D, Braga JU, Barreto ML. Tuberculosis and living conditions in Salvador, Brazil: a spatial analysis. Rev Panam Salud Publica [Internet]. 2014 Nov [cited 2019 Jun 15]; 36:24-30. Available from:

Rev Pre Infec e Saúde. 2019;5:9194 https://www.ncbi.nlm.nih.gov/pubmed/252116 74

21. Pereira AGL, Medronho RA, Escosteguy CC, Valencia LIO, Magalhães MAFM. Spatial distribution and socioeconomic context of tuberculosis in Rio de Janeiro, Brazil. Rev. Saúde Pública [Internet]. 2015 Nov [cited 2019 Jun 15]; 49(1):48-58. Available from: http: //dx.doi.org/10.1590/S00348910.2015049005470

22. Melo TEMP, Resendes APC, Souza-Santos R, Basta PC. Spatial and temporal distribution of tuberculosis in indigenous and non-indigenous of Rondônia State, Western Amazon, Brazil. Cad Saúde Pública [Internet]. 2012 Fev [cited 2019 Jun 15]; 28(2):267-280. Available from: http://dx.doi.org/10.1590/S0102-

\section{X2012000200006}

23. Musenge E, Vounatsou $P$, Collinson M, Tollman $\mathrm{S}$, Kahn $\mathrm{K}$. The contribution of spatial analysis to understanding HIV/TB mortality in children: a structural equation modelling approach. Glob Health Action [Internet]. 2013 Nov [cited 2019 Jun 15]; 3(1):1-9. Available from: https://doi.org/10.3402/gha.v6i0.19266

24. Herrero MB, Arrossi S, Ramos S, Braga JU. Spatial analysis of the tuberculosis treatment dropout, Buenos Aires, Argentina. Rev Saude Pública [Internet]. 2015 Nov [cited 2019 Jun 15]; 49:49-60. Available from: https://doi.org/10.1590/S00348910.2015049005391

25. Wei W, Yuan-Yuan J, Ci Y, Ahan A, Ming-Qin C. Local spatial variations analysis of smearpositive tuberculosis in Xinjiang using geographically weighted regression model. BMC Public Health [Internet]. 2016 Nov [cited 2019 Jun 15]; 16(1):1058-60. Available from: https://doi.org/10.1186/s12889-016-3723-4

26. Wang T, Xue F, Chen Y, Ma Y, Liu Y. The spatial epidemiology of tuberculosis in Linyi City, China, 2005-2010. BMC Public Health [Internet]. 2012 Nov [cited 2019 Jun 15]; 12(1):885-90. Available from: https://doi.org/10.1186/1471 2458-12-885

27. Li XX, Ren ZP, Wang LX, Zhang H, Jiang SW, Chen JX, et al. Co-endemicity of pulmonary tuberculosis and intestinal helminth infection in the people's Republic of China. PLoS Negl Trop 
Dis [Internet]. 2016 Nov [cited 2019 Jun 15]; 10(4): 1-12. Available from: https://doi.org/10.1371/journal.pntd.0004580

28. Cegielski JP, Griffith DE, McGaha PK, Wolfgang $M$, Robinson $C B$, Clark PA, et al. Eliminating tuberculosis one neighborhood at a time. Am J Public Health [Internet]. 2013 Jun [cited 2019 Jun 15]; 103(7):1292-1300. Available from:

https: / / doi.org/10.2105/AJPH.2012.300781

29. Said K, Hella J, Mhalu G, Chiryankubi M, Masika E, Maroa T, et al. Diagnostic delay and associated factors among patients with pulmonary tuberculosis in Dar es Salaam, Tanzania. BMC Infec dises poverty [Internet]. 2017 Nov [cited 2019 Jun 15]; 6(1):64-70. Available from: https://doi.org/10.1186/s40249017-0276-4

30. Yamamura $M$, Freitas $I M$, Santo $N M$, Chiaravalloti NF, Popolin MAP, Arroyo LH, et al. Spatial analysis of avoidable hospitalizations due to tuberculosis in Ribeirao Preto, SP, Brazil (20062012). Rev Saúde Pública [Internet]. 2016 Nov [cited 2019 Jun 15]; 50: 20-30. Available from: http://dx.doi.org/10.1590/S1518-

\subsection{9}

31. Sales CMM, Figueiredo TAM, Zandonade E, Maciel ELN. Spatial analysis on childhood tuberculosis in the state of Espirito Santo, Brazil, 2000 to 2007. Rev Soc Bras Med Trop [Internet]. 2010 Ago [cited 2019 Jun 15]; 43(4): 435-439. Available from:

http://dx.doi.org/10.1590/S0037-

86822010000400020

32. Venâncio TS, Tuan TS, Nascimento LFC. Indidence of tuberculosis in children in the state of São Paulo, Brazil, under spatial approach. Ciênc saúde coletiva [Internet]. 2015 Nov [cited 2019 Jun 15]; 20:1541-1547. Available from: http: / /dx.doi.org/10.1590/1413-

\subsection{4}

33. Montechi LN, Coêlho DMM, Oliveira CAR, Campelo V. Spatial distribution of tuberculosis in Teresina, Piauí, 2005-2007. Epidemiol Serv Saúde [Internet]. 2013 Set [cited 2019 Jun 15]; 22(3):475-482. Available from: http://dx.doi.org/10.5123/S1679-

49742013000300012

Rev Pre Infec e Saúde. 2019;5:9194
34. Santos-Neto M, Yamamura M, Garcia MCC, Popolin MP, Silveira TRS, Arcêncio RA. Spatial analysis of deaths from pulmonary tuberculosis in the city of São Luís, Brazil. J bras pneumol [Internet]. 2014 Oct [cited 2019 Jun 15]; 40(5):543-551. Available from: http://dx.doi.org/10.1590/S1806-

37132014000500011

35. Li L, Xi Y, Ren F. Spatio-temporal distribution characteristics and trajectory similarity analysis of tuberculosis in Beijing, China. Int. J. Environ. Res. Public Health [Internet]. 2016 Nov [cited 2019 Jun 15]; 13(3):291-300. Available from: https://doi.org/10.3390/ijerph13030291

36. Peruhype RC, Acosta LMW, Ruffino NA, Oliveira MMC, Palha PF. The distribution of tuberculosis in Porto Alegre: analysis of the magnitude and tuberculosis-HIV coinfection. Rev esc enferm USP [Internet]. 2014 Nov [cited 2019 Jun 15]; 48(6):1035-1043. Available from: http://dx.doi.org/10.1590/S0080-

623420140000700011

37. Rao H, Shi X, Zhang X. Using the Kulldorff's scan statistical analysis to detect spatio-temporal clusters of tuberculosis in Qinghai Province, China, 2009-2016. BMC Infect Dis [Internet]. 2017 Nov [cited 2019 Jun 15]; 17(1):578-90. Available from: https://doi.org/10.1186/s12879-017-2643y

38. Ribeiro FKC, Pan W, Bertolde A, Vinhas SA, Peres RL, Riley L, et al. Genotypic and spatial analysis of Mycobacterium tuberculosis transmission in a high-incidence urban setting. Clin Infect Dis [Internet]. 2015 Nov [cited 2019 Jun 15]; 61(5):758-766. Available from: https://doi.org/10.1093/cid/civ365

39. Prussing C, Castillo-Salgado C, Baruch N, Cronin WA. Geo-epidemiologic and molecular characterization to identify social, cultural, and economic factors where targeted tuberculosis control activities can reduce incidence in Maryland, 2004-2010. Public health Rep [Internet]. 2013 Nov [cited 2019 Jun 15]; 128(6_suppl3):104-114. Available from: https://doi.org/10.1177/00333549131286S314 40. Ratovonirina $\mathrm{NH}$, Rakotosamimanana $\mathrm{N}$, Razafimahatratra SL, Raherison MS, Refrégier G, Sola $C$, et al. Assessment of tuberculosis spatial hotspot areas in Antananarivo, Madagascar, by 
combining spatial analysis and genotyping. BMC infectious diseases [Internet]. 2017 Nov [cited 2019 Jun 15]; 17(1):562-70. Available from: https://doi.org/10.1186/s12879-017-2653-9

41. Ng IC, Wen TH, Wang JY, Fang CT. Spatial dependency of tuberculosis incidence in Taiwan. PloS one [Internet]. 2012 Nov [cited 2019 Jun 15]; 7(11):1-10. Available from: https://doi.org/10.1371/journal.pone.0050740

42. Rakotosamimanana S, Mandrosovololona V, Rakotonirina J, Ramamonjisoa J, Ranjalahy JR, Randremanana, et al. Spatial analysis of pulmonary tuberculosis in Antananarivo Madagascar: tuberculosis-related knowledge, attitude and practice. PloS one [Internet]. 2014 Nov [cited 2019 Jun 15]; 9(11):1-11. Available from:

https://doi.org/10.1371/journal.pone.0110471 43. Vieira RCA, Prado TN, Siqueira MG, Dietze R, Maciel ELN. Spatial distribution of new tuberculosis cases in Vitória, State of Espírito Santo, between 2000 and 2005. Rev Soc Bras Med Trop [Internet]. $2008 \mathrm{Fev}$ [cited 2019 Jun 15]; 41(1):82-86. Available from: http://dx.doi.org/10.1590/S0037-

\section{7}

44. Rodrigues-Júnior AL, Ruffino-Netto A, Castilho EA. Spatial distribution of the human development index, HIV infection and AIDSTuberculosis comorbidity: Brazil, 1982 - 2007. Rev bras epidemiol [Internet]. 2014 Nov [cited 2019 Jun 15]; 17(Suppl 2):204-215. Available from: http: / /dx.doi.org/10.1590/1809-

4503201400060017

45. Hassarangsee S, Tripathi N, Souris M. Spatial pattern detection of tuberculosis: a case study of Si Sa Ket Province, Thailand. Int J Environ Res Public Health [Internet]. 2015 Nov [cited 2019 Jun 15]; 12(12):16005-16018. Available from: https://doi.org/10.3390/ijerph121215040

46. Dangisso MH, Datiko DG, Lindtjørn B. Spatiotemporal analysis of smear-positive tuberculosis in the Sidama Zone, southern Ethiopia. PloS one [Internet]. 2015 Nov [cited 2019 Jun 15]; 10(6):1$19 . \quad$ Available from: https://doi.org/10.1371/journal.pone.0126369 47. Rao HX, Zhang X, Zhao L, Yu J, Ren W, Zhang $\mathrm{XL}$, et al. Spatial transmission and meteorological determinants of tuberculosis incidence in Qinghai Rev Pre Infec e Saúde. 2019;5:9194
Province, China: a spatial clustering panel analysis. Infect Dis Poverty [Internet]. 2016 Nov [cited 2019 Jun 15]; 5(1):45-55. Available from: https: / /doi.org/10.1186/s40249-016-0139-4

48. Cao K, Yang K, Wang C, Guo J, Tao L, Liu Q, et al. Spatial-temporal epidemiology of tuberculosis in mainland China: an analysis based on Bayesian theory. Int J Environ Res Public Health [Internet]. 2016 Jan [cited 2019 Jun 15]; 13(5):469-80. Available from: https://doi.org/10.3390/ijerph13050469

49. Li XX, Wang LX, Zhang $H$, Jiang SW, Fang $Q$, Chen JX, et al. Spatial variations of pulmonary tuberculosis prevalence co-impacted by socioeconomic and geographic factors in People's Republic of China, 2010. BMC Public Health [Internet]. 2014 Nov [cited 2019 Jun 15]; 14(1):257-60. Available from: https: / /doi.org/10.1186/1471-2458-14-257

50. Santos CB, Hino P, Cunha TN, Villa TCS, Muniz JN. Utilização de um Sistema de Informação Geográfica para descrição dos casos de tuberculose. Bol Pneumol Sanit [Internet]. 2004 Nov [cited 2019 Jun 15]; 12(1):07-12. Available from:

http: / /scielo.iec.gov.br/scielo.php?script=sci_ar ttext\&pid=S0103-460X2004000100002

51. San PA, Oliveira RM. Tuberculosis and socioeconomic indicators: systematic review of the literature. Rev Panam Salud Publica [Internet]. 2013 Nov [cited 2019 Jun 15]; 33(4):294-301. Available from: http://iris.paho.org/xmlui/handle/123456789/9 185

52. Yamamura $M$, Santos $N M$, Freitas $I M$, Rodrigues LBB, Popolin MP, Uchoa SAC, et al. Tuberculosis and social inequity in health: an ecological study using multivariate statistical techniques, São Paulo, Brazil. Rev Panam Salud Publica [Internet]. 2014 Nov [cited 2019 Jun 15]; 35(4):270-7. Available from: https://www.scielosp.org/article/rpsp/2014.v35 n4/270-277

53. Alencar XRA, Fátima PMAM, Souza WV, Montarroyos UR, Diniz GT, Luna CF, et al. Is it better to be rich in a poor area or poor in a rich area? A multilevel analysis of a case-control study of social determinants of tuberculosis. Int $\mathrm{J}$ Epidemiol [Internet]. 2009 Nov [cited 2019 Jun 
15]; 38(5):1285-96. Available from: https://doi.org/10.1093/ije/dyp224

54. Barcellos C. Os indicadores da pobreza e a pobreza dos indicadores: Uma abordagem geográfica das desigualdades sociais em saúde. In: Barcellos C, organizador. A geografia e o contexto dos problemas de saúde. Rio de Janeiro: Abrasco; 2008. p. 107-39. Available from: https: / /www.researchgate.net/publication/3339 71455_Os_Indicadores_da_Pobreza_e_a_Pobreza _dos_Indicadores_Uma_abordagem_geografica_d as_desigualdades_sociais_em_saude

55. Magalhães MAFM, Matos VP, Medronho RA. Evaluation of data of address in SINAN using locally georeferencing of tuberculosis cases by two methods in Rio de Janeiro. Cad Saúde colet [Internet]. 2014 Nov [cited 2019 Jun 15]; 22(2):192-199. Available from: http://dx.doi.org/10.1590/1414-

462X201400020013

56. Santos ZMSA, Frota MA, Martins ABT. Tecnologias em Saúde: da abordagem teórica a construção e aplicação no cenário do cuidado. 1 ed. Fortaleza: EdUECE, 2016. Available from: http://www.uece.br/eduece/dmdocuments/Ebo ok\%20-\%20Tecnologia\%20em\%20Saude\%20-

\%20EBOOK.pdf

\section{COLABORATIONS}

SVMAL, MDS and LDS: participating in substantially contributing in work conception and design; JCN, ADdS and ETO: participating in planning, data analysis and interpretation; KCGMA and MAPN: participating in critical review and approval of the final version of the manuscript. All the authors agree and take the responsibility for the content of this manuscript version to be published.

\section{ACKNOWLEDGMENTS}

Does not apply.

\section{AVAILABILITY OF DATA}

Does not apply.
57. Malucelli A, Stein JAV, Bastos L, Carvalho D, Cubas MR, Paraíso EC. Classification of risk microareas using data mining. Rev Saúde Pública [Internet]. 2010 Nov [cited 2019 Jun 15]; 44(2):292-300. Available from: http://dx.doi.org/10.1590/S003489102010000200009

58. WHO [homepage internet]. Estimated cases and deaths from tuberculosis (TB), 2000-2016: Estimated incidence of TB (all forms) per 100.000 inhabitants, 2016. Available from: http://gamapserver.who.int/gho/interactive_ch arts $/$ tb $/$ cases $/$ atlas. html?indicator $=i 2 \&$ date $=201$ 2

59. Sousa AFL, Marques DM, Monteiro RM, Queiroz AAFL, Andrade D, Watanabe E. Prevention of biofilm formation on artificial pacemakers: is it feasible? Acta paul enferm [Internet]. 2017 Dez [cited 2019 Jun 15]; 30(6):644-650. Available from: $\quad$ http://dx.doi.org/10.1590/19820194201700085

Submitted: 2019-08-13

Accepted: 2019-10-21

Published: 2019-12-15 


\section{FUDING SOURCE}

The Coordination for the Improvement of Higher Education Personnel (CAPES) has provided opportunity for the correspondent author to study abroad for improve the data analysis and interpretation. A fellowship grant was provided for the development of scientific research. Process number: 88881.187327 / 2018-01.

\section{CONFLICTS OF INTEREST}

There are no conflicts of interest to declare.

\section{CORRESPONDENCE}

Shirley Verônica Melo Almeida Lima

Address: R. Cláudio Batista, s/n - Palestina, Aracaju - SE, 49060-108, Brazil

Telephone: +55 7931947202

E-mail: shirleymelo.lima@gmail.com 